\title{
Social work for critical peace: A comparative approach to understanding social work and political conflict
}

\author{
Professor Jim Campbell, School of Social Work and Social Justice, \\ University College Dublin
}

\author{
Professor Vasilios Ioakimidis, University of Essex
}

\author{
Dr Reima Ana Maglajlic, University of Sussex
}

\section{Introduction}

In the last few decades there has been a growing interest in exploring the way in which political conflicts impact upon social work policy and practice. An early edited text by Ramon (2008) used a wide ranging approach to capture the nature of social work engagement with conflicts and disasters across a number of continents. More recently, two leading social work journals have focused on these and other related topics (Spalek \& McDonald, 2012; Ramon \& Zavirsek, 2012). To date, however, there have been few attempts to compare and contrast social work experience in these circumstances.

This paper is the product of a discussion that took place between the authors, built upon our lived and academic experiences of social work and political conflict, during an European Association of Schools of Social Work funded project. To address the lack of comparative analysis in relation to social work and political conflict, it begins with a summary of the 
literature on this topic and then then identifies a number of methodological challenges in carrying out comparative analysis. At the core of the paper is the analysis of three case studies: Northern Ireland, Bosnia Herzogvina $(\mathrm{BiH})$ and Cyprus. It is organised around the themes which emerged from joint analysis of these case studies in relation to social work policy and practice, namely: the impact of colonialism; political systems and identities; and neoliberalism and new social movements. The paper concludes with an appeal for a nuanced approach to social work and political conflict, described as 'social work for critical peace'.

\section{Social work and Political Conflict}

A range of approaches have been used to explain how social workers deal with, and are affected by, political conflict. Some authors developed explanatory theories on historical and contemporary features of political conflict and explored how these are manifested in organisational, practice and educational contexts. For example, the concepts of sectarianism and religious difference are sometimes used to hypothesise how social workers meet the needs of clients (Shamai and Boem, 2001; Author's own 1) The issue of dealing with sectarian conflict in the class room has been studied in Israel (Nutman-Swartz and Dekel, 2009; Moshe-Grodofsky, 2011) and Kosovo (Soumpasi, 2003). A recent European funding initiative has enabled social work educators to create teaching partnerships with victims and survivors of the conflict in Northern Ireland (Author's own 2,3). Others make an appeal for social workers to embrace more radical political approaches involving principles of social justice (Author's own 4; Houston, 2008), political action (Mmatali, 2008; Kreitzer, 2012; Androff, 2012), and social development (Mupedzwisa, 1996; Author's own, 5). The role of social work in addressing the needs of those seeking refuge and asylum are also explored 
(Healy, 2004; Lyons and Stathopolous, 2001; Tasse, 2001; Smith et al, 2003; Briskman and Cemlyn, 2005).

Some authors have set out to test these and other ideas though empirical research. There is some evidence that, despite the difficulties faced by social workers in these circumstances, a range of productive interventions are possible. In an early study of the role of mental health social workers in Northern Ireland (Author's own, 6) it was found that, despite relatively little education and training for these situations, individual and community based strategies were operationalised. Community based interventions have also been used in Palestine, Israel, Lebanon and Africa (Lindsay, 2007; Grodofksy 2011; Doucet and Doucet, 2012; Ochen, 2012). In Israel, a variety of therapeutic approaches were applied to deal with the needs of victims and survivors (Newman-Shwarz, 2015).

Conversely, a number of authors have focused on the traumatic effects of working in these difficult, often dangerous, contexts. In Israel, for example, a number of cross sectional surveys have revealed variable levels of trauma amongst social workers and their families following violent incidents (Lev-Wiesel, 2009; Shamai and Ron, 2008). Social workers involved in helping victims of the 9/11 attack in New York also appeared to experience aspects of trauma (Bauwens and Tosone, 2010). A survey of 1064 health and social care staff in Northern Ireland, which included social workers, also found elevated levels of PTSD (Luce et al, 2009). It is important to also recognise that, where support and protective factors are in place, post-trauma growth is also possible (Baum and Ramon, 2010).

\section{Issues of comparison}


The dearth of comparative study in this literature may be explained, in part, by methodological challenges. Language and terminology used in particular localities may be difficult to translate and travel to other settings (Hantrais, 1995; Hetherington, 1998; Shardlow and Wallis, 2003). Not all concepts and experiences that are reported in and through the English idiom (a common language of international collaboration) make sense in diverse, culturally nuanced circumstances. Thus it can be difficult to locate a consensus on what is understood by 'political conflict', or even 'social work' (Meeuwisse and Sward, 2007). Despite these impediments, comparative analysis is possible in the field of social work policy, practice and education, as evidenced in the seminal work of Lorenz (1993) in his review of the development of European social work.

Given these reservations, our first thought was to develop a typology that was broad enough to understand the role of social work in our chosen case studies whilst not diminishing the importance of 'the particular'(Mabbett and Bolderson, 1999). In our early discussions we agreed that there appeared to be common organising themes that would enable us to carry out tentative comparisons, in terms of how we perceived the orgins and trajectory of the political conflicts and their effect on social work practice in our chosen case studies. The broad domains were: historical contexts, politics, social divisions, nature of the conflict and the social work response. A brief overview and comparison of these domains are presented in

\section{Appendix One.}

Although we could envisage how these domains fitted with our attempts at comparison, what emerged in the next phase of our discussion were other, related, issues that were not fully captured in these early deliberations. This led to a 'turn' or deviation from the road we were travelling. As a result, we agreed to treat the writing of this paper as an encounter, a dialogue that firstly acknowledges the sometimes descriptive ideas that captured our 'own' political conflict and its implications for social work policy and practice. Stimulated by a number of 
iterative discussions, it was possible to move towards a more fluid, ambiguous, understanding of social work (Parton, 1998). It is argued that this topic of social work and political conflict, is ripe for this type of analysis that recognises flux, ambiguity and change in spaces of conflict. The sections that follow seek to illustrate this sense of dialogue where emergent themes are supported first by summaries of case study material, followed by tentative comparisons.

\section{Theme 1: Colonialism past and present}

Forms of social work policy and practice in our three case studies have been shaped by particular histories, as well as colonial, post-colonial and neo-colonial experiences that are often not well understood or acknowledged (Dirlick, 2002).

\footnotetext{
Northern Ireland: The history of the conflict in Northern Ireland is well documented, although ideas about its causes are contested. The period of the plantation of Ulster by the English crown in the sixteenth century created a system of colonial power that was reinforced by sectarian divisions between and within Catholic and Protestant communities. By the nineteenth century uneven industrial growth on the island of Ireland, with a concentration of industry and commerce in the north east, reinforced divisions through structures of class and religion (Bew et al, 1979). These are the contexts that can help explain the modern 'Troubles' in Northern Ireland that followed the partition of the island in 1922. The state in the north was characterised by forms of sectarian discrimination that tended to disadvantage Catholics and working class communities, culminating in demands for civil rights in the 1960s and a long period of conflict between republicans and loyalist paramilitaries and the British state. A sometimes hidden factor is the role that international governments and societies have played in prolonging the conflict or finding ways to deal with its causes. A period of relative peace has been managed since the signing of the Belfast Agreement but ongoing sectarian violence, alongside a failure to address the needs of victims and survivors of the conflict, beset the society.
} 
Bosnia and Herzegovina: The present-day BiH was for nearly five hundred years colonised by the Ottoman (1463-1878) and Austro-Hungarian empires (1878-1918). Following WWI, it became incorporated into the Kingdom of Serbs, Croats, which became Socialist Federal Republic of Yugoslavia in the aftermath of WWII. Not all of the present-day BiH territory experienced these key historic events at the same time. Debates continue about the impact that these histories have had on the country's cultural, social, economic and legal structures (Ruthner, 2008). The legacy of the Ottoman period became more visible in the political debates and reflections on the 1992-1995 war which led to the purposeful destruction of many of the Ottoman-era urban structures (Hajdarpasic, 2008). A powerful narrative involves the concept of an 'uncompromising dichotomy' (ibid.: 720) involving Muslims and Christians, which has tended to oversimplify the complex interplay of socio-economic, political and religious factors in the region. The former Yugoslav slogan of 'Brotherhood and Unity' sought to smooth over such categorisations and supress critical accounts of this dichotomy.

Cyprus: The case study in Cyprus bears some similarities with the other two. The island experienced many phases of colonial conquest, arguably the most significant of which was the impact of British Empire that followed the decline in Ottoman rule in the late nineteenth century. At the time, the Greek speaking community, the most populous ethnic community, embraced British rule, hoping for modernization of the infrastructure as well as enhancement of religious rights for the Christian population. It has been argued however that the colonial process adversely affected the social and economic well-being of the population. Whilst Cyprus was viewed by the colonial power as a strategic geopolitical asset and gateway to the Middle East, society was characterised by underdevelopment, illiteracy and severe poverty (Varnava, 2009). Following two decades of both anti-colonial and intracommunal violence, the Republic of Cyprus finally gained its independence in 1960 introducing a an unrealistically multi-layered, post- colonial political system which encouraged segregation rather than integration. Ethnic violence continued almost uninterrupted and escalated to a full war in 1974 leading to the physical, political and psychological separation of the two communities and the invasion of the Turkish Army in response to failed coup de etat by Greek nationalists, supported by the Military Junta in Greece. The result was the Turkish occupation of $48 \%$ of the island, mostly in the north and, in the south, Greek Cypriots retained the representation of the recognized Republic of Cyprus. 
In this section we view the interaction between the colonizer and the colonized through a postcolonial theoretical prism informed by critical theory. Postmodern and Marxian approaches have significantly influenced the formation of the most important postcolonial discourses and as Authors own (6) suggests, these origins provide a distinct critical edge in the postcolonial analysis which often encourage specific actions towards the multi-level liberation and emancipation of communities, which have suffered from isolation, oppression and discrimination as a result of colonialism. Despite this diversity in origin and knowledge base, one could broadly identify the major domains of discourse that are of interest: a) The historical context of neoliberalism, b) The impact of colonial domination on (primarily) colonized populations as well as the effect of this process on the diverse population of the colonial powers and c) The creation of a theory and praxis that deconstructs the 'given realities' and attempts the emancipation of the oppressed peoples. (ibid.)

These ideas are, we believe, important understanding the social work response in these situations. As Waaldijk (2011) notes, social work tends to accept, often passively, an inheritance of national traditions of providing social assistance without fully acknowledging the struggles of social movements and anti-colonial resistance that led to changes in social and political systems. This phenomenon is recognisable in Cyprus and $\mathrm{BiH}$ where there are unsustainable, multi-layered, neo-colonial political systems that tend to accommodate the interests of colonial and neo-colonial interests. Although sovereignty was nominally transferred to the newly created states, institutionalised divisions and nurtured sectarian politics were an inevitable product. It is therefore crucial that social workers challenge simplistic views of the past in order to play a more visible role in dealing with the legacy of war crimes and chronic injustices that adversely affect targeted communities, in particular ethnic, political or religious minorities. There was little evidence in our discussions about Northern Ireland, Cyprus and $\mathrm{BiH}$ that social workers had a coherent view of the 
complexities of such histories, often because political elites and wider societies are largely still ill-prepared to resolve legacy problems. Even at a global level the main international organisations representing social work have been slow and reluctant to acknowledge the colonial legacies and historical injustices that have fuelled armed conflicts. Partly this is because, in many parts of the world, social work itself was a direct product of these colonial legacies (Author's own 5).

\section{Theme 2: Political systems and the reification of identities}

What became manifest in our discussion were the parallels in dichotomised thinking about the causes and nature of the conflicts, in particular about perceived identities that social workers and clients often shared. Social work practice in each of the case studies appears to be defined and restricted by sectarian politics, either through de jure multilayer post-conflict arrangements or de facto sectarian social divisions. These simplistic dichotomies need to be challenged and deconstructed. For example, in Northern Ireland, the religious labels hide more complex, multiple identities that involve issues of class, national and ethnic categories (Houston, 2008). In terms of the conflict in Cyprus, a rich history of peaceful co-existence between the two major ethnic communities was replaced by narratives on sectarianism that emerged in the mid twentieth century. Such legacies shaped at least some of the history which led to political conflicts, as well as the nature of social work responses prior to, during and after the conflict. In this context, social work has historically either adopted an ahistorical, apolitical approach of superficial neutrality, as in the case of Northern Ireland and $\mathrm{BiH}$, or fully complied with nationalistic narratives which led to the segregation and semimilitarisation of services in Cyprus (and parts of $\mathrm{BiH}$ ). 
Northern Ireland: One of the consequences of the partition of Ireland was the creation of a devolved government in Belfast which, for fifty years was governed by only one party, the Ulster Unionists. Nationalist and Republican parties tended to boycott elections in the early period, but later took their seats, but with little prospect of political influence. These divisions were mirrored at local government level where some degree of gerrymandering of the electoral vote, and maladministration of public housing and other services took place. When the London government prorogued Stormont in 1972 they introduced a period of three decades of Direct Rule which lead to a bureaucratised system of public and social administration and a deficit in local political control. It was during this period of Direct Rule that most of the atrocities and violence took place. The majority of those killed were at the hands of Republican and Loyalist paramilitaries with about eleven per cent caused by state violence (McKittrick et al, 2008). Since 1998 Northern Ireland has had a devolved government where power is currently shared by the two major parties, the Democratic Unionist Party and Sinn Fein, at times in partnership with smaller parties. At the last election an anti-austerity party and the Greens made some gains. This imperfect democratic system can be contrasted with a more vibrant civil society where voluntary sector and community organisations sometimes drive social values and ideas. It has been argued that these new developments offer social worker safer spaces to develop anti-sectarian practices (Authors own 7)

Bosnia and Herzegovina: Since the end of the war, there has been a low voter turnout to elections, explained mainly due to lack of any political alternatives to the nationalist concept of most political parties in $\mathrm{BiH}$ (Author's own 5). Another factor is the complex governance system, established as part of the Dayton Peace Accords in 1996. It includes 13 layers of government at whole-country level, divided into two entities, with one entity further divided into 10 districts (based on the Swiss model). In parallel, there is also one District (Brcko), based on the US local governance model. While the Accords ensured peace, they left behind a system of political representation which is not sustainable, yet any attempts to reform these structures have been resisted, often because of nationalist and ethnic agendas. The governance structure, with a three-member Presidency, comprises of a representatives of three main ethnic groups (Bosniak, Croat and Serb). In 2009, the European Court of Human Rights found this system to be discriminatory against other ethnic groups, based on a case by Sejdic and Finci vs. Bosnia and Herzegovina (as representatives of the Roma and Jewish communities in BiH respectively; for details, see, for example, Milanovic, 2010). However, the verdict remains to be acted upon.

Cyprus: Mainstream historiographical narratives about the conflict routinely over-emphasize on the ethnic dimension of the conflict, while ignoring a rich and powerful tradition of co-existence, tolerance and class unity 
(Trimikliniotis \& Bozkurt, 2012). Suppressed histories of co-existence, however, have started to emerge in recent year as a result of efforts of rapproachement. Despite suppression of trade unionism under British rule, both Greek Cypriot and Turkish Cypriot workers continued organizing and in 1939 the Union of Construction workers achieved the first Labour Collective Agreement which, among others, included employers' contribution for welfare purposes. The general strike of 1948 was a watershed moment for the development of the Cypriot labour movement as the main, if not the only, truly unifying intercommunal institution. It can be argued that the omission of such histories of coexistence and class solidarity can be explained by the preeminance of dominant narratives of nationalism (Trimikliniotis \& Bozkurt, 2012) promoted by the ruling Cypriot elites, constructed on ideas of ethnic purity and "othering". This construction of the 'other' tends to justifying a continuous 'state of emergency' that overshadows attempts to construct cross- communal solidarity; solutions proposed by social movements from below are often vehemently opposed by the ruling classes of both communities and the guarantor 'motherlands'.

A common characteristic of these societies involved a process of 'de-politicisation' of conflict that adversely affected the way that health and social care services were delivered. Social workers, as with other professionals, tended to adopt a 'a mandate to silence' - a collective avoidance of the need to consider the complexites of segregation and conflict. This mandate to silence finds expression through social work curricula, practice and management of services (Authors own 5; Basic, 2010/11). While it can be considered a protective strategy, it negatively impacts both social workers and the communities they work with in short and long term.

\section{Theme 3: Neo-liberal politics and new social movements}

Much of the literature in this area tends to focus on important local and national issues without acknowledging the significance of contemporary international politics and economy, and how social movements grow to resist the impact of neo-liberal policies. 
Northern Ireland: Although the Northern Irish conflict is conventionally viewed to be local in nature, a critical use of the concept of sectarianism suggests that divisions are informed by more complex cultural, ethnic and national identities can be understood in wider international contexts. Despite the peace process, and the role of national and international governments in managing the conflict, Northern Ireland remains as divided as ever with segregated educational and political and social systems (Shirlow and Murtagh, 2006). It has been argued that optimism about the peace process has been undermined by success governments' commitment to neo-liberal economic policies (Coulter, 2014) that failed to address the root causes of the conflict. Yet there are stirring of and for change, with a growing and vibrant gay, lesbian and transgender communities and increased numbers of minority ethnic groups. As a result new and diverse narratives have emerged to challenge conventional politics and community action.

Bosnia and Herzegovina: After the 1992-1995 war, attempts to deal with social divisions tended to be shaped by non-governmental organisations, local as well as international (FOS, BHAS and RSIS, 2005 in Author's own 9). While funding streams for such work had an over-emphasis on inter-ethnic cooperation and activities, it was difficult to ascertain if such mandates were based on organisational values or were due to the need to secure funding. Hence, many activities focused on superficially understood and practiced political correctness based on a Western model of liberal multi-culturalism, rather than genuine attempts to resolve mutual conflicts (Gagnon, 2002, in Helms 2003:111). In general, the majority of the content and execution of their work was oriented to meet the interests of donors, rather than beneficiaries (Author's own, 6).

Cyprus: In the last decade, the financial crisis that engulfed the Republic of Cyprus in conjunction with a wave of privatisations advanced by Turkey in the North of Cyprus, forced trade unions and social movements to engage with the neglected question of post-solution macroeconomics. Indeed, missions representing both sides on the negotiating table carefully avoided to discuss the architecture of the post-solution economics, while domestically both governments unconditionally accepted the holy trinity of neoliberal politics: liberalisation, privatisation, Austerity (Bozkurt, 2013). The fact that neoliberal consensus among ruling classes has been unchallenged for years gave space to the Republic of Cyprus Finance Minister to audaciously suggest that any post-solution constitution should 
incorporate a "Surplus Budget Close"; in other words articulating the desire for politics of permanent austerity to be constitutionally protected.

A unique report on the published by the Pancypriot Federation of Workers in 2015 reconfirmed the urgency of a grassroots agenda which would reclaim the "social issue" over the "national issue". According to the authors of the report assessing the impact of neoliberal politics on the island "it is high time now, for trade unions and workers, to introduce the missing aspects of macroeconomic and social policy in the discussion on reunification since neoliberal austerity policies and social reengineering in both south and north tend actually to recast economy and society in order to establish a new economic paradigm, namely an economic paradigm of neoliberalism and market fundamentalism". (INEK-PEO, 2015).

It is important to account for wider global factors that impact upon policy and practice in these situations. It can be argued that 'liberal peace' approaches, rely heavily on marketization and the neoliberalisation of health and social care services in post conflict societies, invariably resulting in 'failed states' (Chandler, 2010). Post-conflict arrangements based on economic liberalism and free market principles often contribute to the widening of inequalities and perpetuation of poverty that exacerbate the conditions for political conflict. The financial conditions that define liberal transitions to peace (crystalised through constitutions, reconstruction loans and military presence of peace keeping missions) allow little space for the post-conflict societies to decide on their preferred economic policies and approaches to reconstruction (Richmond, 2011). It can also be argued that the problems of such 'failed states' often produce the conditions in which neo-liberal policies can flourish (Pugh, 2002).

In our case studies, it is possible to argue that the orthodoxy of free market economy has never been challenged in the process of reconciliation and transition. The context of an artificial 'state of exception tends to rule out open and meaningful discussions about alternative post-conflict macroeconomic approaches which may better suit the societies 
experiencing transitions. Global institutions, such as the IMF and the World Bank often fund types of social and economic reconstruction that offer legitimacy to neoliberal politics in situations of political conflict, in the case of $\mathrm{BnH}$ and Cyprus, for example, trades union attempts to seek alternative models of growth were stymied. This alternative, left perspective, implies that, instead of consolidating peace, the consequences have been increasing inequalities and the emergence of a 'politics of despair' that has led to the growth of nationalism, zenophobia isolationalism.

These transnational global factors inevitably shape social work practice in situations of political conflict. In the case of Cyprus, for example, social work policy and practice was largely untouched by the demands by social movements, instead it was often shaped by top down policy making. A similar picture emerges for social work in Northern Ireland following the introduction of Direct Rule by the British state in 1972. Where a 'peace industry', involving a complex network of statutory, voluntary and private sector organisations become involved, professionals such as social workers become relatively powerless in affecting social and political change when engaging with clients harmed by political conflict. It has been argued that the views of 'peace experts' are rarely aligned with the real needs of societies affected by war and conflict, as was experienced in $\mathrm{BiH}$ both during and after the war. In addition there is often limited acknowledgement of the ideological and organizational linkages between policies of the colonial administration and the function of transnational organisations (Author's own 6). The result is that peace processes tend to be designed or discussed in policy making systems rather than practices inclusive of vulnerable communities and social workers.

In moving between the international, national and local, we can envisage how social work has responded to the particularities of politics, society and economy in each of our case studies. In these contexts, social workers tend to reach for a 'tool-kit' approach to conflict resolution 
through group, family and individualised interventions, sometimes without reference to cultural literacy. One example is the over use of the PTSD syndrome/diagnostic approach (Richters, 1995; Gilligan, 2009). Where such conflicts have occurred in a variety of states, opportunities for the creation of knowledge 'from below' and by those who have direct experience of colonisation are limited (Waaldijk, 2011), as are possibilities to share such knowledge within mainstream health and social services. This approach tends to ignore or minimise the political context and focus on the technical dimension of the peace process and conflict resolution, as issues of social justice caused by political conflict are often disregarded by organisations and practitioners.

\section{Theme 4: Towards a position of 'social work for critical peace'}

What then appears to have happened in all three case studies was a major contradiction that characterises social work: although the profession is deeply involved and often complicit in practices which could be considered as oppressive (for example the promotion of neoliberal policies and the perpetuation of segregation), in most cases social workers believe in the need for social change and to challenge social injustice.

\footnotetext{
Northern Ireland: It is only in recent years that academic attention has been paid to the role that social work has played in this conflict; number of themes have emerged from this body of knowledge. For most of the Troubles social workers tended to adopt a politically neutral stance, partly because they were often employed by state bureaucracies who espoused this ideology. In many ways social workers, as with other health and social care professionals, were attempting to make the abnormal normal, fitting in with divided services and systems (Author's own, 2). If anything there has been a moderate freeing up of attitudes in the last decade. Some academics have introduced new pedagogical ideas into the class room, where social work students meet to discuss their complex identities and biographies, and work with victims and survivors to create opportunities for new forms of social work practice and social
} 
change (Author's own 3; Author's own 4). But change comes slowly and agencies and politicians remain somewhat fixated with the past and concerned that to move too fast, too soon, is to risk the peace.

Bosnia and Herzegovina: Much of the post 1992-1995 war reconstruction of health and social care services triggered the creation of a parallel system of welfare and support, provided mainly through financial and/or organisational support of international organisations. However, existing statutory services tend to be undermined by the burden of welfare laws that are impossible to implement due to a lack of planning, funding and relevant service provision. In parallel, poverty, together with high unemployment levels, remains one of the biggest problems, with almost one fifth of the population (17.9\%) living in relative poverty (BHAS, 2012). This in turn has had an impact on the way that professionals behave and reflect upon their roles. In particular there is a perception that professionals tend to be marginalised, silent and apolitical (Basic, 2010/11). Such situation is likely to continue due to the lack of '(ethno)political consensus' on how to implement the reforms, now also stipulated as part of the Euro-Atlantic integrations (Basic, 2008/09: 534). Local authors such as Basic advocate the role of social workers as needing to become more political and engage with social justice issues.

Cyprus: The ethnic clashes that followed independence in 1960 rendered the cross-communal nature of social work unfeasible, particularly as a result of the withdrawal of Turkish Cypriots from the parliament, lead to the domination of the profession by Greek Cypriots. In the immediate post war period in the 1970s, social services in the Republic of Cyprus (Greek Cypriot Community) were restructured in way that prioritized the urgent and overwhelming needs of the internally displaced people who had evacuated their towns and villages in the occupied North. Social work education took a more ethnocentric character and education of social workers relied almost exclusive on Helenic ideas whereas social work in the Turkish side took the direction of ethnocentric provision, fully and exclusively supported by the Turkish Republic. It is hardly surprising that, as in the Northern Irish case study, social work is politically, ideologically and culturally defined by the island's division, and there is little or no discussion about the impact of conflict and violence on social work practice and theory. A 'mandate to silence', it can be argued, works in favour of a hidden curriculum that allows the nurturing of nationalist, divisive and often racist ideas. 
We argue that this gap in understanding can be bridged but that social work cannot meaningfully engage in the transformational process of conflict resolution unless the profession builds political alliances with the communities directly affected by the consequences of conflict. Creating spaces for these voices is particularly important given that it is these communities that have the knowledge, expertise by experience, determination and willingness to articulate and implement a coherent vision of social change.

What appears to be the situation in each of the case studies is that there are opportunities for social workers to position themselves depending on their views and experiences of the conflicts. For example, there is a difference between the professionalised, for-fee, responses to social care needs that occur in $\mathrm{BiH}$ and Cyprus, and emerging post war and alternative roles that are more engaged with grassroots voluntary, community-based, and largely informal, organisations. Both pose challenges to social work as a profession: to chose between a more narrow role prescribed by neo-liberal socio-economic principles or to commit to approaches that "promote peace based on social work principles" (IFSW, 2014).

\section{Conclusion}

This paper began with the assertion that, despite a growing in interest in the relationship between social work and political conflict in the academic literature, there have been few attempts to compare and contrast the social work experience between and across case studies. The difficulties in engaging with such a project cannot be understated, not least is making sense the nuances of histories, local divisions and international factors that shape social work practice, but we have found this dialogue both stimulating and challenging. In moving beyond local - sometimes overly descriptive - accounts of social work and political conflict, it 
has been argued that we enter a more ambiguous, critical space in which different sets of relationships emerge and become understood.

In particular, we highlighted the need for an analysis of the impact of the colonial past and present, the influence of neo-liberal policies and new forms of engagement with social movements that challenge bureaucratic orthodoxies. There is no doubt that many social workers in each of the three areas of political conflict may recognise these factors but others, often unintentionally, fail, particularly when there is a resort to technical fixes and micro interventions.

In considering what peace should be in these circumstances it must be more than the absence of conflict. Even where systems of conflict resolution are in place, substantial legacy issues continue to adversely affect both practitioners and clients. Peace can only be meaningful and feasible when it is based on transformative political systems which promote social equality, inclusion, prosperity and a fair distribution of the peace dividend. Hence, future work in this area needs to identify ways for social workers to challenge dominant narratives and practices that perpetuate sectarianism and the militarisation of social services.

Equally, it is crucial for social work to problematize approaches prescribed by the orthodoxy of liberal peace. Inherent in such approaches are neoliberal post-conflict policies that perpetuate social inequalities and class division, undermine stability in fragile societies and fuel the resurgence of sectarianism. In doing so, we hope colleagues embrace a position of "experts of uncertainty" (Stalker, 2003: 228), able to develop mutually trusting and respectful relationships and daring to work creatively and innovatively in this significant area of social work practice. Therefore, we call for social workers to engage in a discussion that aims at articulating and theorising a 'social work for critical peace'; an academic and practice based 
approach which supports societies affected by conflict through challenging the intersecting social, political, historical and cultural injustices.

\section{References}

Abye, T. (2001). Social Work Education with Migrants and Refugees in France. Social work in Europe, 8(3), 3-12.

Author's own 1,2,3,4,5,6,7.

Apostolides, C. \& Güryay, E. (2011). Economic Inderdependence in Cyprus. Nicosia:

Chamber of Commerce and industry.

Basic, S. (2008/2009). O drustvenom statusu profesije socijalnog rada. Fakultet politickih nauka-Godisnjak, $519-536$.

Basic, S. (2010/2011). Socijalni rad u kontektstu dijeljene traumaticne stvarnosti. Fakultet politickih nauka - Godisnjak, 321- 329.

Basic, S. (2013). Social Development and Social Work Profession Challenges in the PostConflict And Transitional Society: Bosnia and Herzegovina case study. Ljetopis Socijalnog Rada, 20(1), 113-138.

Baum, N., \& Ramon, S. (2010). Professional growth in turbulent times. Journal of Social Work, 10(2), 139-156.

Bauwens, J., \& Tosone, C. (2010). Professional posttraumatic growth after a shared traumatic experience: Manhattan clinicians' perspectives on post-9/11 practice. Journal of Loss and Trauma, 15(6), 498-517. 
Bew, P., Gibbon, P., \& Patterson, H. (1979). The state in Northern Ireland, 1921-72: political forces and social classes. Manchester University Press.

BHAS (BH Agency for Statistics) (2012). Household Budget Survey in Bosnia and Herzegovina 2011. Retrieved from: http://www.bhas.ba/saopstenja/2012/HBS_2011_bh.pdf

Briskman, L., \& Cemlyn, S. (2005). Reclaiming humanity for asylum-seekers: A social work response. International Social Work, 48(6), 714-724.

Chandler, D. (2011). The Uncritical Critique of Liberal Peace. Review of International Studies, 36(S1), 137-155.

Coulter, C. (2014) Under Which Constitutional Arrangement Would You Still Prefer to be Unemployed? Neoliberalisam, the Peace Process, and the Politics of Class in Northern Ireland. Studies in Conflict and Terrorism, 37, 763-776.

Dekel, R., \& Baum, N. (2009). Intervention in a shared traumatic reality: A new challenge for social workers. British Journal of Social Work, 40(6), 1927-1944.

Dirlik, A. (2002). Rethinking colonialism: Globalization, postcolonialism, and the nation. Interventions, 4(3), 428-448.Dekel, R., \& Baum, N. (2009). Intervention in a shared traumatic reality: A new challenge for social workers. British Journal of Social Work, 40(6), 1927-1944.

Doucet, D. and Denov, M., 2012. The power of sweet words: Local forms of intervention with war-affected women in rural Sierra Leone. International Social Work, 55(5), pp.612628.

Fay, M.T, Morrisey, M. and Smyth, M. (1999) Northern Ireland's Troubles: The Human Costs. London: Pluto. 
Gilligan, C. (2009). Highly Vulnerable'? Political Violence and the Social Construction of Traumatized Children. Journal of Peace Research, 46(1), 119-134.

Grodofsky, M.M., 2011. Reflections on the Role of a Social Worker in the Israeli-Palestinian Conflict. Reflections: Narratives of Professional Helping (Click on Current or Archives; Registration Optional), 17(4), pp.6-13.

Hajrdarpasic, E. (2008). Out of the ruins of the Ottoman Empire: Reflections on the Ottoman legacy in South-Eastern Europe. Middle Eastern Studies, 44(5), 715-734.

Hantais, L. (1995), Comparative Research Methods. Social Research Update, 13.

Helms, E.L. (2003). Gendered Visions of the Bosnian Future: Women's Activism and Representation in Post-War Bosnia-Herzegovina. PhD thesis, University of Pittsburgh. Retrieved from: https://core.ac.uk/download/files/457/12209040.pdf

Hetherington, R. (1998). Issues in European Child Protection Research. European Journal of Social Work, 1(1), 71-82.

Houston, S. (2008). Transcending ethnoreligious identities in Northern Ireland: Social work's role in the struggle for recognition. Australian Social Work, 61(1), 25-41.

IFSW (2014). Statement of IFSW Europe: Social Work for Peace and Self-Determination Peace is the way. Retrieved from: http://ifsw.org/news/statement-of-ifsw-europe-social-workfor-peace-and-self-determination-peace-is-the-way/

Kreitzer, L. (2012). Social work in Africa: Exploring culturally relevant education and practice in Ghana. University of Calgary Press. 
Lindsay, J. (2007). The impact of the 2nd Intifada: An exploration of the experiences of Palestinian psychosocial counselors and social workers. Illness, Crisis \& Loss, 15(2), 137153.

Luce, A., Firth-Cozens, J., Midgley, S., \& Burges, C. (2002). After the Omagh bomb: Posttraumatic stress disorder in health service staff. Journal of traumatic stress, 15(1), 27-30. Lorenz, W. (1993) Social Work in Europe. London: Routledge.

Lyons, K., \& Stathopoulos, P. (2001). Migration and refugees in Europe: Greek and British perspectives on implications for social work practice and education. European Journal of Social Work, 4(1), 55-63.

Mabbett, D. and Bolderson, H. (1999). Theories and methods in comparative social policy. In Clasen, J. (ed.) Comparative Social Policy: Concepts, Theories and Methods. Oxford: Blackwell, 34-56.

McKittrick, D., Kelters, S., Feeney, B., Thornton, C. and McVea (2008). Lost Lives: The stories of the men, women and children who died as a result of the Northern Ireland Troubles. Edinburgh: Mainstream.

Meeuwisse, A and Sward, H. (2007). Cross-national Comparisons of Social Work: A question of initial assumptions and levels of analysis. European Journal of Social Work, 10(4), 481-496.

Milanovic, M. (2010). Sejdić \& Finci V. Bosnia and Herzegovina. App. Nos. 27996/06 \& 34836/06. At http://www. echr. coe. int. European Court of Human Rights (Grand Chamber), December 22, 2009. American Journal of International Law, 104(4), 636-641. 
Mupedziswa, R. (1996). The challenge of economic development in an African developing country: social work in Zimbabwe. International Social Work, 39(1), 41-54.

Nuttman-Shwartz, O. (2015). Shared resilience in a traumatic reality: A new concept for trauma workers exposed personally and professionally to collective disaster. Trauma, Violence, \& Abuse, 16(4), 466-475.

Nuttman-Shwartz, O., \& Dekel, R. (2008). Training students for a shared traumatic reality. Social Work, 53(3), 279-281.

Occupy Buffer Zone (2013). Occupy vows action despite 'UN bullying'. Retrieved from: http://www.occupybufferzone.info/2013/10/31/occupy-vows-action-despite-un-bullying/

Ochen, E. A. (2012). Protecting and meeting rights of children during conflict? Reflections on the activities of three indigenous social work agencies in Northern Uganda. British Journal of Social Work, 42(6), 1192-1212.

Parton, N. (1998). Risk, advanced liberalism and child welfare: The need to rediscover uncertainty and ambiguity. British Journal of Social Work, 28(1), 5-27.

Pugh, M. (2002). Postwar political economy in Bosnia and Herzegovina: The spoils of peace. Global Governance, 8(4), 467- 482.

Ramon, S. (Ed.). (2008). Social work in the context of political conflict. Birmingham: Venture Press.

Ramon, S. and Zavirsek, D. (2012). Special Issue: Social Work and Armed Conflict International Social Work, 55(5).

Richmond, O. (2011). A Post-Liberal Peace. London: Routledge. 
Richters, A. (1995). Posttraumatische Stress-Stoornis: Een Feministisch-Antropologisch Onderzoek. In Baars, J. and Kal, D.(eds.) Het Uitzicht van Sisyphus: Maatschappelijke Contexten van Geestelijke (On)Gezondheid. Groningen, 175-199.

Ruthner, C. (2008). Habsuburg's little orient: A post/colonial reading of Austrian and German cultural narratives on Bosnia-Herzegovina, 1878-1918. In Ruthner, C., Reynolds, D., Reber, U. \& Detrez, R. (eds.) Wechsel-Wirkungen: The Political, Social and Cultural Impact of the Austro Hungarian Occupation of Bosnia and Herzegovina 1878-1918. New York: Peter Lang.

Shamai, M., \& Boehm, A. (2001). Politically oriented social work intervention. International Social Work, 44(3), 343-360.

Shamai, M., \& Ron, P. (2009). Helping direct and indirect victims of national terror: Experiences of Israeli social workers. Qualitative Health Research, 19(1), 42-54.

Shardlow, S.M. and Walliss, J. (2003). Mapping Comparative Empirical Studies of European Social Work. British Journal of Social Work, 33, 921 - 941.

Shirlow, P. and Murtagh, B. (2006). Belfast: Segregation, Violence and the City. Manchester: Manchester University Press.

Spalek, B., \& McDonald, L. Z. (2012). Special Issue: Social work and political contexts: engagement and negotiation British Journal of Social Work, 42(6).

Stalker, K. (2003). Managing Risk and Uncertainty in Social Work: A literature review. Journal of Social Work, 3(2), 211-233.

Soumpasi, N. (2003). Pilot Project in Kosovo: Training the Trainers on Tolerance: A Social Work Perspective. Social Work in Europe, 10(1), 32-37. 
Trimikliniotis, N. \& Bozcurt, U. (2012). Beyond a divided Cyprus. New York: Palgrave Macmillan.

Varnava, A. (2009). British Imperialism in Cyprus, 1878-1915: The Inconsequential Possession. Manchester: Manchester University Press.

Waaldijk, B. (2011). Social work between oppression and emancipation - histories of discomfort and inspiration in Europe. Social Work and Society, 9(2).

\section{Appendix 1}

\begin{tabular}{|c|c|c|c|}
\hline & Northern Ireland & $\begin{array}{l}\text { Bosnia and } \\
\text { Herzegovina }\end{array}$ & Cyprus \\
\hline History & $\begin{array}{l}\text { British colonial experience. } \\
\text { Division of Ireland in } 1922 . \\
\text { Fifty years of one party rule. } \\
\text { Peace building since } 1998\end{array}$ & $\begin{array}{l}\text { Legacy of territory } \\
\text { being part of the } \\
\text { Ottoman and Austro- } \\
\text { Hungarian Empire. } \\
\text { After WWII, became } \\
\text { one of the founders of } \\
\text { the Non-Allied } \\
\text { Movement. }\end{array}$ & $\begin{array}{l}\text { British Colonial } \\
\text { experience. Direct } \\
\text { Rule from London, } \\
\text { suppression of trade } \\
\text { unionism and civil } \\
\text { liberties. De facto } \\
\text { division of Cyprus } \\
\text { since } 1974 \text { (although } \\
\text { segregation pre- } \\
\text { existed). Check points } \\
\text { re-opened in } 2003 \\
\text { creating a momentum }\end{array}$ \\
\hline
\end{tabular}




\begin{tabular}{|c|c|c|c|}
\hline & & & towards peace \\
\hline Politics & $\begin{array}{l}\text { Unionist one party rule 1922- } \\
\text { 1972. Direct Rule 1972-1998. } \\
\text { Shared power between } \\
\text { Republicans, Nationalists and } \\
\text { Unionists since 1998, } \\
\text { intermittent devolved } \\
\text { administrations hindered by } \\
\text { failure to deal with issue of } \\
\text { legacy }\end{array}$ & $\begin{array}{l}\text { Complex political and } \\
\text { administrative } \\
\text { landscape since 1996, } \\
\text { emphasising and } \\
\text { continuing ethno- } \\
\text { politics. }\end{array}$ & $\begin{array}{l}\text { 1878- 1960: Colonial } \\
\text { Rule. 1960-1974: } \\
\text { Independent Cyprus. } \\
\text { 1974- to date: divided } \\
\text { Cyprus. In the } \\
\text { southern part, } \\
\text { Republic of Cyprus. In } \\
\text { the North, de facto } \\
\text { creation of Turkish } \\
\text { Republic of Northern } \\
\text { Cyprus. }\end{array}$ \\
\hline $\begin{array}{l}\text { Social } \\
\text { divisions }\end{array}$ & $\begin{array}{l}\text { Sectarianism, ethnic and } \\
\text { cultural differences, class } \\
\text { politics marginalised }\end{array}$ & $\begin{array}{l}\text { Ethnic differences } \\
\text { embedded in school } \\
\text { curricula and } \\
\text { administrative } \\
\text { organisation of the } \\
\text { country. }\end{array}$ & $\begin{array}{l}\text { Ethnic and religious } \\
\text { divisions. Trade } \\
\text { unions the most } \\
\text { reliable inclusive } \\
\text { institution during } \\
\text { period of separation. }\end{array}$ \\
\hline $\begin{array}{l}\text { Nature of the } \\
\text { conflict }\end{array}$ & $\begin{array}{l}3,700 \text { deaths, up to } 100,000 \\
\text { physically and psychologically } \\
\text { traumatised, continuing low } \\
\text { level sectarianism, division in } \\
\text { public housing and education }\end{array}$ & $\begin{array}{l}\text { At a minimum, } 2 \% \text { of } \\
\text { the pre-war population } \\
(89,186 \text { of } 4,368,514 \\
\text { people) were either } \\
\text { killed or disappeared } \\
\text { in the } 1992-95 \text { war. } \\
\text { The majority ( } 57,992) \\
\text { were Muslims, }\end{array}$ & $\begin{array}{l}\text { 3,500 deaths (the } \\
\text { number is contested). } \\
200,000 \text { internally } \\
\text { displaced. } 2001 \\
\text { missing persons. } \\
\text { Creation The } \\
\text { Committee on Missing } \\
\text { Persons in Cyprus }\end{array}$ \\
\hline
\end{tabular}




\begin{tabular}{|c|c|c|c|}
\hline & & $\begin{array}{l}\text { followed by Serbs } \\
(19,398) \text {. Precise } \\
\text { figures are still } \\
\text { impossible to achieve } \\
\text { due to the variety and } \\
\text { politicised nature of } \\
\text { reporting for all such } \\
\text { figures. }\end{array}$ & $\begin{array}{l}\text { (CMP) supported by } \\
\text { UN }\end{array}$ \\
\hline $\begin{array}{l}\text { Social work } \\
\text { response }\end{array}$ & $\begin{array}{l}\text { Neutral, apolitical, yet well- } \\
\text { educated and trained. } \\
\text { Resistance by agencies for } \\
\text { change }\end{array}$ & $\begin{array}{l}\text { Technocratic, } \\
\text { marginalised, with } \\
\text { minimal involvement } \\
\text { in the post-war } \\
\text { reforms. }\end{array}$ & $\begin{array}{l}\text { Responses vary } \\
\text { between silence (no } \\
\text { "Cyprus issue" } \\
\text { modules in social } \\
\text { work curricula) to } \\
\text { nationalism } \\
\text { (segregated social } \\
\text { services) }\end{array}$ \\
\hline
\end{tabular}

